\title{
RELEVANSI NILAI LABA, NILAI BUKU EKUITAS, ARUS KAS OPERASI DAN DIVIDEN
}

\author{
Yulianni \\ Sugi Suhartono* \\ Program Studi Akuntansi, Kwik Kian Gie School of Business, Jl. Yos Sudarso Kav. 87, Jakarta 14350
}

\begin{abstract}
The relevance of the value of accounting information presented must have the ability to explain the value of a company. Accounting information in the form of financial statements is said to be relevant if the information can be useful for investors in making decisions and the reaction of investors when information is announced that can be observed through stock price movements, because stock prices reflect the value of the company. The theories used in this study are the theory of clean surplus, signaling theory, and theory of market efficiency. Based on the purposive sampling method obtained as many as 79 companies, with a total of 237 samples. The analysis techniques used are pooling test, classic assumption test, descriptive statistical test, $F$ test, $t$ test, and test coefficient of determination. The data used is secondary data obtained from www.idx.co.id. The results showed that earnings, equity book values, operating cash flows, and dividends proved to have a positive influence on stock prices.
\end{abstract}

Keywords : Earnings, book value of equity, operating cash flows, dividends, and stock price

\begin{abstract}
Abstrak
Relevansi nilai informasi akuntansi yang disajikan harus memiliki kemampuan untuk menjelaskan nilai suatu perusahaan. Informasi akuntansi berupa laporan keuangan dikatakan relevan jika informasi tersebut dapat bermanfaat bagi para investor dalam pengambilan keputusan dan adanya reaksi pemodal pada saat informasi diumumkan yang dapat diamati melalui pergerakan harga saham, karena harga saham mencerminkan nilai perusahaan. Teori yang digunakan dalam penelitian ini adalah teori clean surplus, teori signalling, dan teori efisiensi pasar. Berdasarkan metode purposive sampling diperoleh sebanyak 79 perusahaan, dengan total 237 sampel. Teknik analisis yang digunakan adalah uji pooling, uji asumsi klasik, uji statistik deskriptif, uji F, uji t, dan uji koefisien determinasi. Data yang digunakan merupakan data sekunder yang diperoleh dari www.idx.co.id. Hasil penelitian menunjukkan bahwa laba, nilai buku ekuitas, arus kas operasi, dan dividen terbukti memiliki pengaruh positif terhadap harga saham.
\end{abstract}

Kata kunci : Laba, Nilai buku ekuitas, Arus kas operasi, Dividen, dan Harga saham

\section{Pendahuluan}

Akhir-akhir ini muncul klaim yang mengatakan bahwa informasi akuntansi yang diperoleh dari laporan keuangan telah kehilangan relevansinya bagi investor yang diakibatkan oleh perubahan perekonomian, yaitu dari perekonomian industrial ke perekonomial berteknologi tinggi dan berorientasi jasa (Francis dan Schipper, 1999). Kegunaan informasi akuntansi khususnya laba, nilai buku, dan arus kas semakin memburuk karena dampak perubahan operasi perusahaan dan perubahan kondisi perekonomian tidak terefleksi secara cukup dalam sistem pelaporan sekarang (Lev dan Zarowin, 1999). Selain itu, seringkali informasi-informasi akuntansi yang dilaporkan dalam laporan keuangan seringkali dengan nilai perusahaannya yang berbeda, misalkan : banyak perusahaan yang memiliki kinerja baik tetapi nilai perusahaannya rendah 
dan sebaliknya kinerja perusahaan kurang baik tetapi nilai perusahaannya tinggi.

*Alamat kini: Institut Bisnis dan Informatika Kwik Kian Gie, Jl. Yos Sudarso Kav. 87, Jakarta 14350 Penulis untuk Korespondensi: Telp. (021) 65307062 Ext. 236, Email: sugi.suhartono@ @wikkiangie.ac.id

Akan tetapi informasi akuntansi berupa laporan keuangan bukan merupakan satusatunya faktor yang dapat menyebabkan pergerakan harga saham yang terjadi di bursa, melainkan ada faktor-faktor lain diluar dari faktor fundamental (informasi akuntansi laporan keuangan). Penelitian tentang relevansi nilai informasi akuntansi di negara berkembang seperti Indonesia yang menghubungkan variabel informasi akuntansi dengan harga saham pasar modal. Karena variabel-variabel tersebut dapat menimbulkan bias pada koefisien relevansi nilai informasi akuntansi yang dilaporkan. Variabel-variabel yang digunakan seperti profitabilitas, nilai buku per saham, laporan arus kas, dan dividen yang memiliki hasil penelitian yang berbeda-beda terhadap harga saham.

Laba mempunyai kandungan informasi (information content) yang penting bagi pasar modal. Laba dikatakan mengandung informasi apabila pasar bereaksi dengan pengumuman laba (earnings announcement). Laba akuntansi yang diumumkan melalui laporan keuangan merupakan sinyal dari sekumpulan informasi yang tersedia bagi pasar modal informasi dalam (inside information) berupa kebijakan manajemen, pengembangan produk, strategi yang dirahasiakan, dan sebagainya yang tidak tersedia oleh publik akhirnya akan tercermin dalam angka laba (per saham) yang dipublikasikan dalam laporan keuangan (Suwardjono, 2014: 490). Dengan demikian, pengumuman laba per saham mempunyai kandungan informasi yang penting bagi investor karena kemampuannya dalam memprediksi pendapatan di masa yang akan datang, sehingga dapat dikatakan laba memiliki relevansi nilai terhadap harga saham.

Menurut Ohlson (1995) nilai buku (book value) per lembar saham menunjukkan aktiva bersih (net assets) yang dimiliki oleh pemegang saham dengan memiliki satu lembar saham. Karena aktiva bersih adalah sama dengan total ekuitas pemegang saham, maka nilai buku per lembar saham adalah total ekuitas dibagi dengan jumlah saham yang beredar. Nilai buku ekuitas dikatakan memiliki relevansi nilai apabila meringkas informasi mengenai nilai bersih dari sumber daya perusahaan yang dapat dilihat dari perusahaan pada umumnya berasosiasi positif dan signifikan terhadap harga saham (Jahfer dan Lebbe, 2017; Astuti dan Yunita, 2018), bahkan penelitian yang dilakukan oleh (Kwon, 2009) menunjukkan bahwa nilai buku memiliki relevansi nilai dibandingkan dengan nilai laba dan arus kas operasi.

Kas berguna sebagai modal untuk dilakukannya produksi dan diharapkan dengan produksi yang dihasilkan akan memberikan pengembalian kas yang memuaskan guna memenuhi berbagai kebutuhan perusahaan. Informasi dalam arus kas terutama akan berguna pada saat perusahaan sedang mengalami kesulitan keuangan atau kerugian, karena pada saat tersebut informasi laba yang tersedia tidak lagi memiliki relevansi nilai. Hal ini sejalan dengan penelitian Yendrawati dan Pratiwi (2014) yang menyatakan bahwa arus kas memberikan pengaruh yang lebih besar terhadap harga saham dibandingkan laporan neraca dan laporan laba rugi. Sehingga, arus kas memiliki peranan dalam mempertahankan kelangsungan hidup suatu entitas dan menjadi informasi yang menarik bagi para pengguna laporan keuangan. Dengan demikian, perusahaan yang memiliki arus kas yang positif mencerminkan kinerja yang baik dalam menghasilkan kas dan setara kas, sedangkan perusahaan dengan arus kas negatif akan mencerminkan bahwa perusahaan sedang berada dalam kondisi defisit atau sedang mengalami kesulitan dana. Oleh karena itu, perusahaan yang baik akan memberikan sinyal yang baik bagi para investor karena para investor yakin bahwa perusahaan yang memiliki arus kas yang baik khususnya arus kas operasi akan mampu untuk melunasi seluruh 
kewajibannya dan memiliki cukup dana untuk memberikan dividen pada para investor.

Kebijakan pembagian dividen merupakan kebijakan manajemen untuk menentukan besarnya bagian laba yang akan dibagikan kepada para pemegang saham dan yang akan ditahan perusahaan untuk selanjutnya diinvestasikan kembali. Hal tersebut dapat terjadi dikarenakan jika perusahaan mengeluarkan pengumuman mengenai pembagian dividen, publik akan merespon positif pengumuman tersebut. Respon dari masyarakat didasarkan pada penilaian masyarakat yang berpendapat bahwa perusahaan tersebut memiliki laba yang besar sehingga mampu membagikan dividen. Dengan pandangan seperti itulah maka investor merasa bisa mendapatkan keuntungan jika menanamkan sahamnya di perusahaan tersebut, yang dapat menyebabkan naiknya harga saham. Didukung dalam penelitian (Ndubuisi et al., 2018) yang menyatakan bahwa dividen memiliki relevansi nilai terhadap harga saham. Tujuan penelitian ini adalah untuk mengetahui apakah laba, nilai buku ekuitas, arus kas operasi dan dividen memiliki relevansi nilai terhadap harga saham.

\section{Teori Clean Surplus}

Teori ini mengasumsikan bahwa investor memiliki keyakinan dan preferensi yang homogen. Asumsi berikutnya adalah terdapat hubungan surplus bersih antara ekuitas dan laba. Hubungan surplus bersih ini berarti bahwa seluruh perubahan ekuitas selain yang berasal dari transaksi modal, berupa pembagian dividen atau penambahan modal, juga berasal dari laba perusahaan. Namun hal tersebut telah memiliki beberapa keberhasilan dalam menjelaskan dan memprediksi nilai perusahaan yang sesungguhnya. Kondisi-kondisi inilah yang menyatakan bahwa data-data akuntansi memiliki relevansi nilai. Penelitian relevansi nilai dirancang untuk menetapkan manfaat nilai-nilai akuntansi terhadap penilaian ekuitas perusahaan. Konsep relevansi nilai tidak terlepas dari kriteria relevan dari standar keuangan karena jumlah angka akuntansi akan relevan jika jumlah yang disajikan merefleksikan informasi-informasi yang relevan dengan penelitian suatu perusahaan dan memiliki suatu prediksi berkaitan dengan nilai pasar sekuritas.

\section{Teori Signalling}

Menurut Jogiyanto, (2013:392) informasi yang dipublikasikan akan memberikan signal bagi para investor dalam pengambilan keputusan investasi. Pada saat informasi diumumkan, pelaku pasar akan terlebih dahulu menginterpretasikan dan menganalisis informasi tersebut sebagai sinyal baik (good news) atau sinyal buruk (bad news). Jika pengumuman tersebut mengandung nilai positif, maka investor akan tertarik untuk melakukan perdagangan saham, dengan demikian pasar akan bereaksi yang tercermin melalui perubahan dalam volume perdagangan saham (Suwardjono, 2014).

\section{Teori Efisiensi Pasar}

Pasar dikatakan efisiensi setengah kuat jika harga-harga sekuritas saham secara penuh mencerminkan semua informasi yang dipublikasikan termasuk informasi yang berada di laporan-laporan keuangan perusahaan emiten. Bentuk pasar efisien di atas dapat dilihat bahwa pasar efisien bentuk semi strong adalah bentuk pasar efisien yang berkaitan langsung dengan penelitian relevansi nilai, karena semua informasi dalam laporan keuangan khususnya informasi akuntansi haruslah merupakan informasi yang tersedia di publik, hal ini untuk melihat seberapa cepat pasar akan bereaksi pada saat informasi tersebut dipublikasikan (Scott, 2015:122). Dengan adanya informasi tersebut maka harga saham di pasar dapat menjadi landasan dalam mengukur instrumen keuangan yang berguna dalam pengambilan keputusan ekonomi bagi para investor.

\section{Relevansi Nilai}

Relevansi nilai informasi akuntansi merupakan konsep yang membahas mengenai berbagai makna dan ukuran yang berkenaan dengan akuntansi. Informasi akuntansi diperkirakan memiliki nilai relevansi, karena informasi akuntansi secara statistik berhubungan dengan nilai pasar saham (Beaver, 1989). Penelitian mengenai value relevance informasi akuntansi menggunakan $R^{2}$ yang 
bertujuan untuk menjelaskan informasi akuntansi menggunakan analisis regresi linier berganda (Mufidah, 2017). Relevansi nilai dicerminkan melalui harga saham. Harga saham yang digunakan adalah harga saham penutupan (closing price) karena reaksi pasar terhadap harga saham akan tercermin dalam pergerakan saham pada saat tanggal publikasi atau pengumuman laporan keuangan. Tanggal 30 April merupakan batas akhir publikasi laporan keuangan sehingga pasar sudah mempunyai ekspektasi terhadap kinerja perusahaan, dengan asumsi bahwa pada waktu tersebut harga saham telah mencerminkan semua informasi yang tersedia di pasar dan semua laporan keuangan sudah terpublikasi sebelum 30 April.

\section{Hipotesis}

$\mathrm{Ha}_{1}$ : Laba berpengaruh positif terhadap harga saham.

$\mathrm{Ha}_{2}$ : Nilai buku ekuitas berpengaruh positif terhadap harga saham.

$\mathrm{Ha}_{3}$ : Arus Kas Operasi berpengaruh positif terhadap harga saham.

$\mathrm{Ha}_{4}$ : Dividen berpengaruh positif terhadap harga saham.

\section{Metode Penelitian}

\section{Objek Penelitian}

Obyek penelitian dalam penelitian ini adalah perusahaan manufaktur yang terdaftar di Bursa Efek Indonesia pada periode 2015-2017. Sampel dalam penelitian ini diambil dengan metode purposive sampling tipe judgement sampling. Purposive sampling merupakan pengambilan sampel yang dilakukan sesuai dengan tujuan penelitian yang telah ditetapkan atau kriteria tertentu.

\section{Variabel Penelitian}

\section{a. Variabel Dependen}

Variabel dependen yang digunakan dalam penelitian ini adalah harga saham penutupan (closing price) karena reaksi pasar terhadap harga saham akan tercermin dalam pergerakan saham pada saat tanggal publikasi atau pengumuman laporan keuangan. Tanggal 30 April merupakan batas akhir publikasi laporan keuangan sehingga pasar sudah mempunyai ekspektasi terhadap kinerja perusahaan, dengan asumsi bahwa pada waktu tersebut harga saham telah mencerminkan semua informasi yang tersedia di pasar dan semua laporan keuangan sudah terpublikasi sebelum 30 April.

\section{b. Variabel Independen}

\section{Laba}

Laba per saham atau Earning per Share (EPS) yang digunakan dalam penelitian ini adalah laba bersih yang didistribusikan kepada pemilik entitas dibagi dengan jumlah saham yang beredar (Gitman dan Zutter, 2015: 87).

\section{EPS \\ $=\frac{\text { Laba bersih yang didistribusikan untuk pemilik entitas }}{\text { Jumlah saham yang beredar }}$}

\section{Nilai Buku Ekuitas \\ Variabel nilai buku ekuitas menggunakan proksi pengukuran yaitu}

nilai buku per lembar saham (book value per share). Nilai buku per lembar saham yang digunakan dalam penelitian ini adalah nilai buku saham biasa pada akhir tahun fiskal yang dihitung berdasarkan total ekuitas dibagi dengan jumlah saham yang beredar (Astuti, 2018).

$$
\text { BVPS }=\frac{\text { Total Ekuitas }}{\text { Jumlah saham yang beredar }}
$$

\section{Arus Kas Operasi}

Variabel arus kas operasi dalam penelitian ini diukur menggunakan arus kas operasi per lembar saham (cash flow operating per share). CFOPS merupakan hubungan antara kas yang diperoleh dari hasil operasi perusahaan dengan jumlah saham yang beredar. Jumlah arus kas masuk dan arus kas keluar yang digunakan untuk operasional perusahaan yang merupakan penghasilan utama pendapatan perusahaan dan kegiatan 
lainnya di luar aktivitas investasi dan pendanaan meliputi pengumpulan dan pengeluaran kas (Mufidah, 2017; Yendrawati dan Pratiwi, 2014).

$$
\text { CFOPS }=\frac{\text { Arus Kas Operasi }}{\text { Jumlah saham yang beredar }}
$$

\section{Dividen}

Variabel dividen dalam penelitian ini diukur menggunakan dividen per share (DPS). DPS merupakan total dividen tunai yang dibagikan kepada pemegang saham dibandingkan dengan jumlah saham yang beredar (Aminah et al., 2016; Abdurraham et al., 2017).

$$
D P S=\frac{\text { Dividen }}{\text { Jumlah saham yang beredar }}
$$

\section{Teknik Pengambilan Sampel}

Pengambilan sampel dilakukan dengan nonprobabilistic sampling metode purposive sampling dengan adanya kriteria yang ditentukan agar memperoleh sampel yang sesuai. Berikut ini kriteria-kriteria yang ditetapkan antara lain :

Tabel 1

Kriteria Pengambilan Sampel

\begin{tabular}{lc}
\hline Keterangan Perusahaan Sampel & Jumlah \\
\hline Perusahaan manufaktur yang terdaftar di BEI periode 2015-2017 & 143 \\
Perusahaan manufaktur yang di-delisting selama periode 2015-2017 & $(1)$ \\
Perusahaan yang data laporan keuangannya tidak lengkap & $(25)$ \\
Perusahaan yang menyajikan laporan keuangan dalam mata uang asing & $(31)$ \\
Outlier & $(7)$ \\
Jumlah perusahaan pertahun & 79 \\
Jumlah periode penelitian 2015-2017 & 3 \\
Jumlah data observasi selama 2015-2017 & $\mathbf{2 3 7}$ \\
\hline
\end{tabular}

\section{Teknik Analisis Data}

\section{a. Statistik Deskriptif}

Menurut (Ghozali, 2016:19), statistik deskriptif memberikan gambaran atau deskripsi suatu data yang dilihat dari nilai rata-rata (mean), standar deviasi, varian, maksimum, minimum, sum, range, kurtoris, dan skewness atau kemencengan distribusi.

b. Uji Kesamaan Koefisien (Uji Pooling)

Penelitian ini menggunakan data time series sehingga perlu dilakukan suatu pengujian untuk mengetahui apakah pooling data penelitian (penggabungan data time series dan cross-sectional) dapat dilakukan. Pengujian ini nantinya untuk mengetahui apakah ada perbedaan koefisien antara regresi yang ada.

c. Uji Asumsi Klasik

\section{1) Uji Normalitas}

Uji normalitas bertujuan untuk menguji apakah dalam model regresi, variabel pengganggu atau residual memiliki distribusi normal (Ghozali, 2016: 154). Model regresi yang baik adalah jika model tersebut terdistribusi secara normal. Jika Asymp Sig $\geq 0.05$, maka model regresi menghasilkan nilai residual yang berdistribusi normal.

\section{2) Uji Multikolinearitas}

Uji multikolinearitas bertujuan untuk menguji apakah model regresi ditemukan adanya hubungan korelasi antara satu variabel independen (Ghozali, 2016:103). Hasil yang diinginkan adalah tidak ditemukannya hubungan linear antar variabel independen (tidak terjadi multikolinearitas). Jika nilai tolerance $\geq$ 
0.1 dan VIF $\leq 10$, maka dapat diartikan bahwa tidak terdapat multikolinearitas.

\section{3) Uji Autokorelasi}

Uji autokorelasi bertujuan untuk menguji apakah dalam model regresi linier ada korelasi antara kesalahan pengganggu pada periode $\mathrm{t}$ dengan kesalahaan pengganggu pada periode sebelumnya (Ghozali, 2016: 107). Jika Asymp Sig $\geq$ 0.05 , maka tidak tolak $\mathrm{H}_{0}$ yang artinya residual random atau tidak terjadi autokorelasi.

\section{4) Uji Heterokedastisitas}

Uji heteroskedastisitas bertujuan menguji apakah dalam model regresi terjadi ketidaksamaan variance dari residual satu pengamatan ke pengamatan yang lain. Model regresi yang baik adalah yang homokedasitas atau tidak terjadi heteroskedastitas (Ghozali, 2016:134). Jika nilai $c^{2}$ hitung $<c^{2}$ tabel, maka tolak $\mathrm{H}_{0}$ yang artinya tidak terjadi heterokedastisitas.

\section{d. Analisis Regresi Ganda}

Analisis regresi ganda adalah uji yang dilakukan untuk meramalkan hasil hubungan antara satu variabel dependen dengan beberapa variabel independen untuk menjawab hipotesis penelitian. Regresi ganda ini dilakukan dengan bantuan SPSS 20.0. Berikut adalah regresi ganda yang digunakan dalam penelitian ini :

$$
\begin{aligned}
& \text { CP }=\beta_{0}+\beta_{1} \text { EPS }+\beta_{2} \text { BVPS }+ \\
& \beta_{3} \text { CFOPS }+\beta_{4} \text { DPS }+\varepsilon
\end{aligned}
$$

\section{Hasil dan Pembahasan}

Analisis statistik deskriptif dari variabel-variabel yang diujikan dalam penelitian ini disajikan dalam tabel yang menunjukkan bahwa sampel yang digunakan dalam penelitian ini berjumlah 237 sampel. Variabel harga saham (CP) memiliki rata-rata sebesar $1.517,363882$ dengan nilai terendah sebesar 50 dimiliki oleh PT Kertas Basuki Rachmat Indonesia Tbk (KBRI) dan PT Indo Acidatama Tbk

\section{e. Uji Signifikansi Simultan (Uji F)}

Uji statistik $F$ untuk menunjukkan apakah semua variabel independen yang dimasukkan dalam model mempunyai pengaruh secara bersama-sama (simultan) terhadap variabel dependen (Ghozali, 2016: 96). Jika nilai $\mathrm{F}_{\text {hitung }}>$ $\mathrm{F}_{\text {tabel }}$ atau sig $<0.05$, berarti tolak $H_{0}$, artinya model layak digunakan untuk penelitian.

f. Uji Koefisien Regresi Secara Parsial (Uji t)

Uji statistik t menunjukkan seberapa jauh pengaruh suatu variabel independen secara individual dalam menerangkan variasi variabel dependen (Ghozali, 2016: 97). Jika nilai $t_{\text {tabel }}$ atau nilai sig $<0.05$, berarti tolak $H_{0}$, artinya variabel independen berpengaruh signifikan terhadap variabel dependen.

g. Uji Koefisien Determinasi $\left(R^{2}\right)$

Koefisien determinasi $\left(\boldsymbol{R}^{2}\right)$ pada intinya dilakukan untuk mengukur seberapa jauh

kemampuan model dalam menerangkan variasi variabel dependen. Nilai koefisien determinasi sendiri berkisar antara $0 \leq \boldsymbol{R}^{2} \leq 1$ (Ghozali, 2016: 95). Jika nilai $\boldsymbol{R}^{\mathbf{2}}$ kecil berarti bahwa kemampuan variabel-variabel independen dalam menjelaskan variasi variabel dependen sangat terbatas dan sebaliknya apabila nilainya mendekati satu maka variabel-variabel independen memberikan hampir semua informasi yang dibutuhkan untuk memprediksi variabel-variabel dependen.

\section{Analisis Deskriptif}

(SRSN) yang artinya bahwa saham tersebut kurang diminati oleh investor sehingga permintaan untuk saham tersebut tidak banyak dan nilai tertinggi sebesar 15,075 dimiliki oleh PT Multi Bintang Indonesia Tbk (MLBI) yang artinya bahwa saham diminati oleh nvestor sehingga permintaan akan saham tersebut meningkat, dengan standar deviasi sebesar 2.385,8009506. 
Tabel 2

Hasil Statistik Deskriptif

\begin{tabular}{lccccc}
\hline \multicolumn{1}{c}{ Variabel } & $\mathrm{N}$ & Minimum & Maximum & Mean & Std. Deviation \\
\hline CP & 237 & 50.00 & $15,075.00$ & $1,517.3639$ & $2,385.8010$ \\
EPS & 237 & -295.13 & 875.81 & 72.0805 & 158.2505 \\
BVPS & 237 & $-2,971.81$ & $8,293.24$ & 877.3746 & $1,393.4903$ \\
CFOPS & 237 & -472.73 & $1,228.79$ & 119.4130 & 222.0135 \\
DPS & 237 & 0.00 & 511.00 & 34.7734 & 78.8315 \\
Valid N (listwise) & 237 & & & & \\
\hline
\end{tabular}

Rata-rata untuk Earnings per Shares (EPS) 72,080549 dengan nilai terendah sebesar -295,1300 dimiliki oleh PT Sierad Produce Tbk yang artinya bahwa perusahaan itu hanya mampu memperoleh laba per lembar saham sebesar -295,1300 dan tertinggi 875,8100 dimiliki oleh PT Jembo Cable Company Tbk yang artinya bahwa perusahaan tersebut mampu memperoleh laba per lembar saham sebesar 875,8100 dengan standar deviasi 158,2504985 .

Rata-rata untuk Book Value per Shares (BVPS) 877,374641 dengan nilai terendah 2.971,8100 dimiliki oleh PT Jakarta Kyoei Steel Works Tbk yang artinya bahwa perusahaan hanya mampu memperoleh aktiva bersih yang dimiliki oleh setiap investor untuk setiap lembar sahamnya sebesar $-2.971,8100$ dan tertinggi 8.293,2400 dimiliki oleh PT Asahimas Flat Glass Tbk yang artinya bahwa perusahaan tersebut mampu memperoleh aktiva bersih yang dimiliki oleh setiap investor untuk setiap lembar sahamnya sebesar 8.293,2400 dengan standar deviasi 1.393,4903824.

Rata-rata untuk Cash Flow Operating per Shares (CFOPS) 119,413038 dengan nilai terendah $-472,7300$ dimiliki oleh PT Indal Aluminium Industry Tbk yang artinya bahwa perusahaan tersebut sedang mengalami masalah dalam pengelolaan piutang sehingga menyebabkan arus kas negatif karena arus kas masuk dari pelanggan lebih kecil dibandingkan dengan arus kas yang dikeluarkan oleh perusahaan untuk membayar gaji karyawan dan lainnya dan tertinggi sebesar 1.228,7900 dimiliki oleh PT Semem Indonesia Tbk dengan standar deviasi 222,0135395 dan rata-rata untuk Dividen per Shares (DPS) 34,773418 dengan nilai terendah 0 yang artinya bahwa perusahaan itu tidak melakukan pembagian dividen dan tertinggi 511,0 dimiliki oleh PT Multi Bintang Indonesia Tbk dengan standar deviasi 78,8315176.

Hasil Uji Kesamaan Koefisien dapat dilihat bahwa nilai signifikansi untuk D1_EPS, D1_BVPS, D1_CFOPS, D1_DPS, D2_EPS, D2_BVPS, D2_CFOPS, D2_DPS memiliki nilai signifikansi lebih besar dari 0,05 . Hasil ini menunjukan bahwa data dalam penelitian telah lolos uji kesamaan koefisien sehingga data yang diuji dapat digabung atau dipool.

\section{Uji Kesamaan Koefisien (Uji Pooling)}

Tabel 3

Hasil Uji Kesamaan Koefisien

\begin{tabular}{lc}
\hline Variabel & Sig. \\
\hline D1_EPS & 0.0615 \\
D1_BVPS & 0.1885 \\
D1_CFOPS & 0.1215 \\
D1_DPS & 0.3225 \\
D2_EPS & 0.1460 \\
D2_BVPS & 0.4795 \\
D2_CFOPS & 0.2420
\end{tabular}




\section{Uji Asumsi Klasik}

Tabel 4

Hasil Uji Asumsi Klasik

\begin{tabular}{|c|c|c|c|c|c|}
\hline \multirow[b]{3}{*}{ Variabel } & \multicolumn{5}{|c|}{ Jenis Pengujian } \\
\hline & \multirow{2}{*}{ Normalitas } & \multicolumn{2}{|c|}{ Multikolinearitas } & \multirow{2}{*}{ Autokorelasi } & \multirow{2}{*}{ Heterokedastisitas } \\
\hline & & Tol & VIF & & \\
\hline \multirow[t]{2}{*}{ EPS } & \multirow{3}{*}{$\begin{array}{l}\text { Asymp. Sig }(2-\text { tailed }) \\
=0,000163<0,05\end{array}$} & 0,218 & 4,577 & \multirow{3}{*}{$\begin{array}{l}\text { Asymp. Sig (2-tailed) } \\
=0,1345>0,05\end{array}$} & \multirow{2}{*}{$\begin{array}{l}c^{2} \text { hitung }<c^{2} \text { tabel, } \\
72,522<272,8358\end{array}$} \\
\hline & & 0,551 & 1,816 & & \\
\hline BVPS & & & & & \\
\hline CFOPS & & 0,309 & 3,235 & & \\
\hline DPS & & 0,381 & 2,627 & & \\
\hline
\end{tabular}

\section{a. Uji Normalitas}

Berdasarkan hasil pengujian yang dapat dilihat pada tabel 4.3 , dengan menggunakan uji one-sample Kolmogorov Smirnov menyatakan bahwa nilai Asymp. Sig (2-tailed) sebesar $0,000163<0,05$. Hal ini berarti bahwa semua data tidak berdistribusi normal. Akan tetapi, masalah asumsi normalitas tersebut dapat diabaikan apabila sampel yang digunakan setidaknya berjumlah 30 sampel (Bowerman et al., 2014:278). Untuk penelitian ini, data yang digunakan adalah sebanyak 237 sampel, sehingga data dapat dianggap berdistribusi normal.

\section{b. Uji Multikolinearitas}

Berdasarkan hasil pengujian yang dapat dilihat pada tabel 4.3, menyatakan bahwa tidak terjadi masalah pada uji ini dikarenakan nilai tolerance $>0,1$ dan nilai VIF < 10 yang berarti bahwa tidak adanya korelasi yang terjadi antara variabel independen.

\section{c. Uji Autokorelasi}

Berdasarkan hasil pengujian autokorelasi yang dapat dilihat pada tabel 4.3 menggunakan uji Run Test menunjukkan nilai Asymp. Sig (2tailed) sebesar 0,269 karena nilai dari hasil pengujian berada di atas tingkat kepercayaan yaitu 5\% maka dapat disimpulkan bahwa residual random (acak) atau tidak terjadi autokorelasi antar nilai residual.

\section{d. Uji Heterokedastisitas}

Berdasarkan hasil pengujian heterokedastisitas yang dapat dilihat pada tabel 4.3 dengan menggunakan uji White menunjukkan nilai $c^{2}$ hitung < $c^{2}$ tabel yaitu $72,522<272,8358$, maka variabel independen yang signifikan secara statistik tidak mempengaruhi variabel dependen sehingga dapat disimpulkan model regresi tidak mengandung adanya heterokedastisitas.

\section{e. Uji Signifikansi Simultan (F)}

Berdasarkan hasil pengujian signifikansi simultan (uji F) pada tabel 4.4 dapat dilihat bahwa nilai sig. sebesar $0,000<0,05$. Hal ini menunjukkan bahwa variabel EPS, BVPS, CFOPS, dan DPS secara bersama-sama (simultan) mempunyai pengaruh terhadap variabel independen nya yaitu harga saham $(\mathrm{CP})$.

f. Uji Koefisiensi Regresi Secara Parsial (t)

Tabel 5

Hasil Uji Signifikansi t

\begin{tabular}{lcc}
\hline Variabel & $\beta$ & Sig. \\
\hline (Constant) & 353,422 & 0,000
\end{tabular}




\begin{tabular}{lcc} 
EPS & 1,939 & 0,012 \\
BVPS & 0,199 & 0,005 \\
CFOPS & 1,508 & 0,002 \\
DPS & 19,262 & 0,000 \\
\hline
\end{tabular}

1) Berdasarkan hasil pengujian koefisien regresi (uji t) pada tabel 4.5 dapat dilihat bahwa variabel profitabilitas yang diwakili oleh EPS pada penelitian ini memiliki nilai signifikansi sebesar $0,024 / 2=$ $0,012<0,05$, serta koefisien betanya bertanda positif. Hal ini membuktikan bahwa terdapat cukup bukti bahwa nilai laba memiliki pengaruh positif terhadap harga saham, sehingga tolak $\mathrm{H}_{0}$.

2) Berdasarkan hasil pengujian koefisien regresi (uji t) pada tabel 4.5 dapat dilihat bahwa variabel BVPS pada penelitian ini memiliki

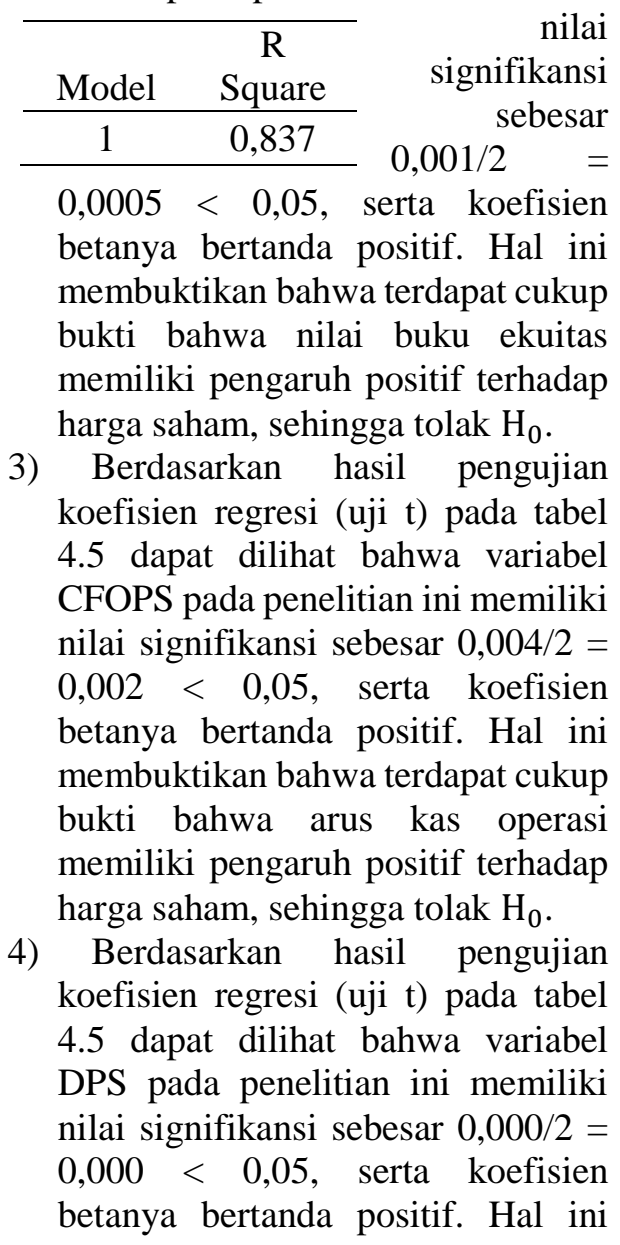

membuktikan bahwa terdapat cukup bukti bahwa dividen memiliki pengaruh positif terhadap harga saham, sehingga tolak $\mathrm{H}_{0}$.

Berdasarkan hasil perhitungan maka dapat dirumuskan persamaan regresi berganda sebagai berikut :

$$
\begin{gathered}
\mathrm{CP}=353,422+1,939 \text { EPS }+0,199 \\
\text { BVPS }+1,508 \text { CFOPS + 19,262 DPS }
\end{gathered}
$$

\section{g. Uji Koefisien Determinasi $\left(R^{2}\right)$}

Berdasarkan hasil uji koefisiensi determinasi pada tabel 4.6 dapat dilihat besarnya nilai $\mathrm{R}^{2}$ adalah 0,837 , nilai tersebut dapat diartikan bahwa $83,7 \%$ variasi $\mathrm{CP}$ dapat dijelaskan oleh variabel EPS, BVPS, CFOPS, dan DPS. Sedangkan sisanya $16,3 \%$ dijelaskan oleh variabel lainya di luar penelitian.

\section{Tabel 6}

\section{Hasil Uji Koefisien Determinasi}

\section{Pembahasan}

1) Laba berpengaruh positif terhadap harga saham

Berdasarkan pada hasil penelitian, variabel nilai laba per lembar saham (EPS) terbukti memiliki relevansi nilai terhadap harga saham, maka $\mathrm{Ha}_{1}$ dapat diterima. Hal tersebut dapat dilihat dari nilai beta sebesar 1,939 dan tingkat signifikansi sebesar 0,024 $<0,05$ hasil penelitian ini sesuai dengan penelitian (Ndubuisi et al., 2018; Astuti, 2018). EPS berpengaruh positif terhadap harga saham menunjukkan bahwa informasi akuntansi memiliki relevansi nilai karena investor merespon positif perkembangan nilai laba. Sesuai dengan signalling theory maka informasi akan adanya peningkatan laba merupakan sinyal baik bagi investor. Investor menganggap bahwa peningkatan laba dalam suatu 
perusahaan mencerminkan kinerja yang baik dari suatu perusahaan sehingga investor tertarik untuk berinvestasi karena perusahaan dapat menghasilkan return saham yang tinggi. Semakin tinggi laba per saham yang diberikan perusahaan akan memberikan pengembalian yang cukup baik sehingga akan mendorong investor untuk melakukan investasi yang lebih besar dan harga saham perusahaan akan meningkat.

2) Nilai buku ekuitas berpengaruh positif terhadap harga saham

Berdasarkan pada hasil penelitian, variabel nilai buku ekuitas per lembar saham (BVPS) terbukti memiliki relevansi nilai terhadap harga saham. Hal tersebut dapat dilihat dari nilai beta sebesar 0.199 dan tingkat signifikansi sebesar $0,001<0,05$, sehingga $\mathrm{Ha}_{2}$ dapat diterima, yang berarti bahwa semakin tinggi nilai buku ekuitas maka semakin tinggi juga harga saham. Hal itu juga berarti bahwa investor masih beranggapan bahwa nilai buku perusahaan merupakan informasi yang penting dikarenakan nilai buku per lembar saham menggambarkan kekayaan investor untuk setiap lembar saham yang dimiliki, sehingga apabila terjadi kenaikan pada nilai buku per lembar saham maka secara tidak langsung pasar akan merespon baik juga melalui kenaikan harga saham. Nilai buku ekuitas dikatakan memiliki relevansi nilai apabila meringkas informasi mengenai nilai bersih dari sumber daya perusahaan yang dapat dilihat dari perusahaan pada umumnya berasosiasi positif dan signifikan terhadap harga saham (Jahfer dan Lebbe, 2017; Astuti dan Yunita, 2018). Pasar efisien adalah bentuk pasar yang berkaitan langsung dengan penelitian relevansi nilai, karena semua informasi dalam laporan keuangan khususnya informasi akuntansi haruslah merupakan informasi yang tersedia di publik, hal ini untuk melihat seberapa cepat pasar akan bereaksi pada saat informasi tersebut dipublikasikan (Scott, 2015:122). Adanya informasi mengenai harga-harga saham sekuritas maka harga saham di pasar dapat menjadi landasan dalam mengukur instrumen keuangan yang berguna dalam pengambilan keputusan ekonomi bagi para investor.

3) Arus kas operasi berpengaruh positif terhadap harga saham

Berdasarkan pada hasil penelitian, variabel arus kas operasi per lembar saham (CFOPS) terbukti memiliki relevansi nilai terhadap harga saham dan memiliki koefisien yang bernilai positif. Dapat dilihat dari nilai beta sebesar 1,508 dengan tingkat signifikan sebesar $0,002<0,05$, maka $\mathrm{Ha}_{3}$ dapat diterima. Semakin tinggi arus kas operasi perusahaan maka semakin tinggi kepercayaan investor terhadap perusahaan tersebut. Berdasarkan data PT INDS Tbk dapat dilihat bahwa terjadi kenaikan arus kas operasi setiap tahunnya yang diikuti juga dengan kenaikan harga saham, hal ini berarti bahwa arus kas operasi memiliki pengaruh positif terhadap harga saham. Hal ini sejalan dengan penelitian Yendrawati dan Pratiwi (2014) yang menyatakan bahwa arus kas memberikan pengaruh yang lebih besar terhadap harga saham dibandingkan laporan neraca dan laporan laba rugi. Informasi arus kas merupakan sinyal positif bagi investor.

4) Dividen berpengaruh positif terhadap harga saham

Berdasarkan pada hasil penelitian, variabel arus kas operasi per lembar saham (CFOPS) terbukti memiliki relevansi nilai terhadap harga saham dengan koefisien yang bernilai positif. Hal tersebut dapat dilihat dari nilai beta sebesar 19,262 dan tingkat signifikansi sebesar 0,000<0,05, maka $\mathrm{Ha}_{4}$ diterima. Salah satu alas an investor membeli saham adalah untuk mendapatkan dividen. DPS tinggi akan mencerminkan bahwa perusahaan memiliki prospek yang baik dan akan menarik investor yang memanfaatkan dividen untuk keperluan konsumsi. Sehingga apabila DPS yang diterima naik tentu saja hal ini akan menarik investor untuk membeli saham perusahaan tersebut. Dengan banyaknya saham yang dibeli maka harga saham perusahaan akan naik di pasar modal. Hasil penelitian ini sesuai dengan penelitian yang dilakukan oleh Ndubuisi et al. (2018) yang menyatakan bahwa dividen memiliki relevansi nilai 
terhadap harga saham. Pembagiab dividen merupakan sinyal positif bagi investor untuk melakukan investasi pada perusahaanperusahaan.

\section{Kesimpulan dan Saran}

Berdasarkan analisis dan pembahasan, maka kesimpulan penelitian ini adalah laba, nilai buku ekuitas, arus kas, dividen operasi terbukti memiliki pengaruh positif terhadap harga saham. Penelitian ini memiliki keterbatasan yang perlu diperbaiki untuk penelitian-penelitian selanjutnya.

Penelitian ini memiliki keterbatasan yang perlu diperbaiki agar menjadi lebih baik, maka terdapat beberapa saran yang dapat diberikan oleh peneliti untuk penelitian selanjutnya yaitu antara lain memperpanjang periode penelitian dan menggunakan sampel yang lebih banyak, mengembangkan model ini ke semua sektor dengan berbagai jenis industri sebagai variabel kontrol, menggunakan variabel independen lain diluar dari penelitian ini seperti Debt to Asset Rasio (DAR), Debt to Equit Rasio (DAR), Return of Equity (ROE), Return of Investment (ROI), penelitian selanjutnya diharapkan dapat menguji menggunakan variabel moderasi atau variabel intervening seperti nilai penjualan atau nilai liabilitas perusahaan, rasio-rasio keuangan, dan sebagainya, penelitian selanjutnya dapat menggunakan harga saham tanggal publikasi dengan window 3 hari sebelum tanggal publikasi dan 3 hari setelah tanggal publikasi, agar penggunaan data harga saham tidak hanya pada satu titik saja.

\section{Daftar Pustaka}

Abdurrahman, Salim, M. A., dan Slamet, A. R. (2017), Pengaruh Dividen Per Share (DPS), Net Profit Margin (NPM), dan Return on Equity (ROE) Terhadap Harga Saham Perusahaan Industri Manufaktur Yang Tercatat di BEI 2012-2015, Jurnal Riset Manajemen, Hal 124-135.

Aminah, N., Arifati, R., dan Si, M. (2016), Pengaruh Dividen Per Share, Returun on Equity, Net Profit Marjgin, Return on Investment, dan Return on Asset Terhadap
Harga Saham Pada Perusahaan Real Estate dan Property yang Terdaftar di Bursa Efek Infonesia Periode Tahun 2011-2013, Journal Of Accounting, Vol.2, No.2, Maret 2016.

Astuti, P., Yunita L.S., dan Armalia R.W., (2018), Analisis Pengaruh Return On Equity, Earnings Per Share, Price To Book Value, Book Value Per Share, Price Earning Ratio dan Kepemilikan Institusional terhadap Harga Saham Perusahaan, Jurnal Ekonomi, Vol.20, No.2, Hal 170-183.

Beaver, W. H. (1989), Financial Reporting An Accounting Revolution, Edisi 3, USA: Pine Tree Composition, Inc.

Bowerman, B.L., O'Connell, R. T., \& Murphree, E. S. (2014), Business Statistics in Practice Using Modeling, Data and Analytic, Edisi 7, New York: McGraw-Hill/Irwin, Hal: 278.

Francis, J., \& Schipper, K, (2013), Have Financial Statements Lost Their Relevance?, Journal of Accounting Research, Vol.37, No.2, pp 319-352.

Ghozali, I. (2016), Aplikasi Analisis Multivariate Dengan Program IBM SPSS 23, Edisi 8, Semarang: Badan Penerbit Univesitas Diponegoro.

Gitman, L. J. and Zutter, C.J. (2013). Principles of Managerial Finance, Edisi 13, London: Pearson Education Limited.

Ikatan Akuntan Indonesia, (2009), Standar Akuntansi Keuangan per 1 Juli 2009, Jakarta: Ikatan Akuntansi Indonesia.

Ikatan Akuntan Indonesia, (2015), Standar Akuntansi Keuangan per Efektif 1 Januari 2015, Jakarta: Ikatan Akuntansi Indonesia.

Ikatan Akuntan Indonesia, (2017), Standar Akuntansi Keuangan Per 1 Januari 2017, Jakarta: Ikatan Akuntansi Indonesia. 
Jahfer, A., \& Lebbe, M. S. (2017), Value Relevance of Accounting Information: Evidence from Sri Lanka, Proceedings of The Third International Symposium, SEUSL: 6-7 July 2013.

Jogiyanto (2013), Teori Portofolio dan Analisis Investasi. Edisi 7, Yogyakarta: BPFEYogyakarta.

Kwon, G. J. (2009), The Value Relevance of Book Values, Earnings and Cash flows: Evidence from South Korea. International Journal of Business and Management, Vol.4, No.10, pp 28.

Lev, B., \& Zarowin, P. (1999), The Boundaries of Financial Reporting and How to Extend Them. Journal of Accounting Research, Vol.37, No.2, pp 353.

Livnat, J., \& Zarowin, P. (1990), The Incremental Information Content of Cash-Flow Components. Journal of Accounting and Economics, Vol.13, No.1, pp 25-46.

Mufidah, E. (2017), Analisis Laba, Arus Kas Operasi Dan Nilai Buku Ekuitas Terhadap Harga Saham, Ejournal Stiedewantara, Vol.12, No.1, pp 47-62.

Ndubuisi, N., C, A. M., Chinyere, O. J., \& Leonard, N. C. (2018), Effect Of Accounting Information On Market Share Price Of Selected Firms Listed On Nigeria Stock Exchange, International Journal of Recent Advances in Multidisciplinary Research, Vol.5, No.1, pp 3366-3374.

Ohlson, J. (1995). Earnings, Book-Values, and Dividends In Equity Valuation. Contemporary Accounting Research, Vol.11, No.2, pp 661-687.

Scott, W. (2015), Financial Accounting Theory (7th ed.), Edisi 7, USA: Pearson Canada, Inc.
Suwardjono. (2014), Teori Akuntansi Perekayasaan Pelaporan Keuangan, Edisi Ketiga, BPFE-Yogyakarta.

Watts, R. L., \& Zimmerman, J. L. (1990), Positive Accounting Theory, New Jersey: Prentice Hall, Inc.

www.idx.co.id

Yendrawati, R., \& Pratiwi, R. S. I. (2014), Relevansi Nilai Informasi Laba dan Arus Kas terhadap Harga Saham. Jurnal Dinamika Manajemen, Vol.5, No.2, pp 161-170. 